\title{
PERLAKUAN BENIH TOMAT DENGAN Trichoderma harzianum dan Gliocladium virens UNTUK MENEKAN SERANGAN Fusarium oxysporum PENYEBAB PENYAKIT LAYU FUSARIUM
}

\section{TOMATO SEEDS TREATMENT WITH Trichoderma harzianum and Gliocladium virens for SUPPRESSING FUSARIUM WILT}

\author{
Wiwit Rahayu, R.R. Rukmowati Brotodjojo*, Nurngaini \\ Universitas Pembangunan Nasional Veteran Yogyakarta, Yogyakarta, Indonesia \\ ${ }^{*}$ Corresponding author: brotodjojo@upnyk.ac.id
}

\begin{abstract}
ABSTRAK
Salah satu kendala dalam peningkatan produksi tomat adanya penyakit layu Fusarium. Tujuan penelitian adalah mengetahui efektivitas jamur agen hayati Trichoderma harzianum dan Gliocladium virens untuk menekan serangan Fusarium oxysporum penyebab penyakit layu dengan perlakuan benih tomat. Penelitian dilaksanakan di Laboratorium Pengamatan Hama dan Penyakit Tanaman (LPHPT), Pandak, Bantul, DIY. Uji in vitro dilakukan untuk mengetahui mekanisme antagonisme agen hayati dilanjutkan dengan uji in vivo untuk mengetahui efektivitas kedua agen hayati tersebut pada tanaman tomat. Percobaan di rumah kaca disusun menggunakan Rancangan Acak Lengkap (RAL) dengan 7 perlakuan dan 4 ulangan yaitu kontrol tanpa perlakuan, $F$. oxysporum, Trichoderma harzianum, Gliocladium virens, $F$. oxysporum vs. T.harzianum, F. oxysporum vs. G. virens dan F. oxysporum vs. T.harzianum+ G. virens. Data dianalisis menggunakan Analysis of Variance (ANOVA) pada taraf $\alpha=5 \%$ dan untuk mengetahui beda nyata antar perlakuan maka dilanjutkan uji Duncan's Multiple Range Test (DMRT) taraf $\alpha=5 \%$. Uji in vitro menunjukkan bahwa $T$. harzianum, $G$. virens, atau kombinasi T.harzianum+ G. virens dapat menghambat pertumbuhan jamur F.oxysporum melalui mekanisme parasitisme dan kompetisi. Uji in vivo menunjukkan kombinasi T.harzianum+ G.virens menghasilkan indeks vigor, tinggi tanaman, jumlah daun, bobot segar akar, bobot kering akar nyata paling tinggi dan persen tanaman yang terserang layu Fusarium nyata paling rendah. Hasil penelitian ini menunjukkan perlakuan kombinasi T.harzianum+ G.virens efektif dalam menekan penyakit layu Fusarium.
\end{abstract}

Kata kunci : Tomat, Fusarium, Trichoderma harzianum, Gliocladium virens

\begin{abstract}
Tomato plant production has problems that often occur, namely Fusarium wilt disease. The aim of this study was to determine the effectiveness of the biological agent fungi Trichoderma harzianum and Gliocladium virens for seeds treatment to prevent Fusarium wilt. The research was conducted at Plant Pest and Diseases Monitoring Laboratory, Pandak, Bantul, DIY. The research was conducted using in vitro test for assessing antagonism mechanisms followed by in vivo test to assess the effectivity of these two biolological agents to prevent Fusarium wilt. Glass house experiment was arranged in a Completely Randomized Design (CRD) with 7 treatments (untreated control, Fusarium oxysporum, T. harzianum, G. virens, F. oxysporum vs.T.harzianum, F. oxysporum vs. G.virens and F. oxysporum vs. T.harzianum+G.virens) with 4 replications. Data were
\end{abstract}


analyzed using Analysis of Variance (ANOVA of $\alpha=5 \%$ ) and followed by Duncan's Multiple Range Test (DMRT $\alpha=5 \%$ ). In vitro tests showed that $T$. harzianum, $G$. virens or combination of the two fungi suppreased the growth of F.oxysporum by parasitisation and competition. In vivo test showed that combination of T.harzianum + G.virens resulted in significanty higher indeks vigor, plant height, number of leaves, root fresh weight, root dry weight, and lowered percent of infected plants. The results showed that the combination treatment of T.harzianum + G.virens was effective in suppressing Fusarium wilt disease.

Keywords: Tomatoes, Fusarium, Trichoderma harzianum, Gliocladium virens

\section{PENDAHULUAN}

Tanaman tomat (Solanum lycopersicum L.) merupakan salah satu komoditas unggulan yang memiliki prospek baik. Tanaman tomat memliki peran penting antara lain sebagai sumber pangan, vitamin, mineral, bahan baku industri, obat-obatan serta kosmetik (Supriati \& Siregar 2009). Tanaman tomat termasuk rentan terhadap serangan patogen. Salah satu patogen yang menyerang tanaman tomat adalah Fusarium oxysporum penyebab penyakit layu yang menyerang berkas pembuluh tanaman. Fusarium oxysporum dapat menyerang lebih dari 150 spesies tanaman dan tergantung spesies atau kultivar yang diserang dapat bersifat spesies spesifik (Fravel et al., 2003; Bertoldo et al., 2015). Gejala awal penyakit layu Fusarium terlihat pada daun bagian bawah menguning yang diikuti dengan layunya bagian atas tanaman, sehingga seluruh tanaman menjadi layu kemudian mati (Srinivas et al., 2019). Kehilangan hasil akibat serangan $F$. oxysporum pada tanaman tomat bervariasi tergantung saat serangan terjadi dan tingkat keparahan penyakit. Tanaman tomat bisa tidak memberikan hasil sama sekali ketika tanaman layu kemudian mati sebelum menghasilkan buah.

Pengendalian penyakit layu Fusariun pada tanaman tomat dapat dilakukan dengan berbagai teknik antara lain penanaman varietas tahan, pengendalian secara kimiawi, hayati maupun fisik (McGovern, 2015). Pengendalian secara kimiawi dengan fumigasi tanah menggunakan metil bromida sebelum tanam banyak dilakukan tetapi mempunyai dampak negatif terhadap lingkungan. Penanaman varietas tahan merupakan salah satu teknik pengendalian yang efektif dan ramah lingkungan, tetapi apabila dilakukan terus menerus akan memunculkan ras Fusarium baru (Fravel et al., 2003). Pengendalian secara hayati dapat dilakukan dengan pemberian mikroorganisme yang bersifat antagonis terhadap Fusarium, antara lain Trichoderma spp. dan Gliocladium spp. Trichoderma spp. dan Gliocladium spp. dapat melindungi tanaman dari serangan patogen karena menghasilkan berbagai senyawa antibiotik dan memparasit jamur patogenik. Selain itu kedua jamur tersebut juga dapat menstimulasi pertumbuhan tanaman (Harman et al., 2004b; Steward \& Hill, 2014). Kedua jamur ini diketahui dapat memarasit miselium jamur Rhizoctonia dan Sclerotium, serta menghambat pertumbuhan banyak jamur seperti Phytium, Fusarium dan mengurangi penyakit yang disebabkan oleh patogen tersebut (Agrios, 1996). Gliocladium sp. yang diisolasi dari pohon Eucryphia cordifolia menghasilkan senyawa organic yang dapat mematikan jamur Pythium ultimum dan Verticillum 
dahlia serta menghambat jamur lain yang bersifat patogenik pada tanaman (Stinson et al., 2003).

Jamur $F$. oxysporum merupakan jamur tular tanah. Klamidospora $F$. oxysporum dapat bertahan lama di tanah tanpa adanya inang (Khan et al., 2017, Cha et al., 2016). Kondisi ini menyebabkan tanaman yang ditanam pada tanah yang pernah terinfestasi $F$. oxysporum mudah terinfeksi. Salah satu cara untuk mencegah serangan $F$. oxysporum pada tanaman muda adalah dengan memberi perlakuan benih sebelum ditanam. Perlakuan benih dengan $T$. harzianum T22 pada tanaman jagung di lapangan dapat menurunkan kolonisasi biji oleh Fusarium verticillioides dan menurunkan kontaminasi mikotoksin dari patogen $F$. verticillioides (Ferrigo et al., 2014). Perlakuan benih melon dengan $T$. polysporum dan diulang pada 15 hari setelah pindah tanam dikombinasikan dengan aplikasi fertigasi kompos cair kosentrasi $50 \mathrm{~mL} / \mathrm{L}$ seminggu sekali secara nyata dapat menekan layu Fusarium sebesar 32,2\% dan meningkatkan produksi buah sebesar 27\% (Gava \& Pinto, 2016). Tomat Varietas Tymoti yang ditanam pada tanah yang diinokulasi $F$. oxysporum dan diberi perlakuan Trichoderma sp. dengan kepadatan spora $10^{6}$ dan $10^{8}$ mengalami keparahan penyakit 13,9 dan $8,3 \%$, sedang tanaman tomat yang diperlakukan dengan Benomy tingkat keparahan penyakit mencapai $27,8 \%$ dan yang tidak dikendalikan keparahan penyakit mencapai 100\% (Ghufron et al., 2017). Penelitian lain menunjukkan aplikasi $G$. virens dapat menekan tejadinya penyakit rebah semai tanaman kapas yang disebabkan oleh Phytium ultimum dan Rhizoctonia solani sebesar lebih dari $50 \%$ (Howell, 1982). Walaupun sudah ada penelitian penggunaan Trichoderma spp untuk mengendalikan layu Fusarium tapi belum ada penelitian penggunaan Gliocladium untuk mengendalikan layu Fusarium. Penelitian ini bertujuan untuk mengetahui pengaruh pemberian jamur Trichoderma harzianum, Gliocladium virens, dan kombinasi T.harzianum dengan G. virens untuk perlakuan benih tomat dalam menekan penyakit Fusarium.

\section{METODE PENELITIAN}

Penelitian dilaksanakan di Laboratorium Pengamatan Hama dan Penyakit Tanaman (LPHPT), Bantul, DIY. Penelitian menggunakan uji in vitro dilanjutkan in vivo yang disusun dalam Rancangan Acak Lengkap (RAL) dengan 7 perlakuan dan 4 ulangan yaitu kontrol tanpa perlakuan, Fusarium oxysporum, Trichoderma harzianum, Gliocladium virens, F. oxysporum + T. harzianum, F. oxysporum + G. virens dan kombinasi Fusarium +T.harzianum+ G.virens. Dengan demikian seluruhnya terdapat 28 unit percobaan dan setiap unit percobaan terdiri dari 20 tanaman, sehingga terdapat 560 unit tanaman.

\section{Perbanyakan Patogen dan Agen Hayati}

Isolat Fusarium oxysporum, Trichoderma harzianum, Gliocladium virens merupakan koleksi LPHPT Bantul. Masing-masing jamur ditumbuhkan pada media PDA di cawan petri secara tersendiri untuk digunakan pada pengujian selanjutnya.

\section{Uji Antagonis In Vitro}

Uji antagonis agen hayati $T$. harzianum dan $G$. virens terhadap jamur F.oxysporum dilakukan secara in vitro dengan metode kultur ganda (dual culture) 
di media PDA pada cawan petri (diameter $9 \mathrm{~cm}$ ). Isolat jamur agen hayati $T$. harzianum dan G. virens dan jamur patogen F.oxysporum dipotong dengan diameter $5 \mathrm{~mm}$. Pada kontrol, isolat F.oxysporum diletakkan di tengah cawan petri. Untuk uji antagonisme masing-masing agen hayati, isolat $T$. harzianum atau G. virens diletakkan secara berhadapan jamur patogen F.oxysporum dengan jarak $3 \mathrm{~cm}$ pada garis tengah cawan petri. Untuk uji antagonisme $T$. harzianum+G. virens vs F.oxysporumi, isolat patogen diletakkan berseberangan dengan kedua isolat agen hayati dengan jarak masing-masing $3 \mathrm{~cm}$. Semua isolat tersebut diinkubasikan pada suhu ruang $\left(28 \pm 1^{\circ} \mathrm{C}\right)$, dan diamati tiap hari selama 7 hari. Tingkat antagonisme diukur sebagai persentase daya hambat pertumbuhan jamur F.oxysporum yang dihitung dengan rumus $[(a-b) / a] \times 100$, dimana a adalah diameter isolat F.oxysporum pada kontrol dan $b$ adalah diameter isolat F.oxysporum pada perlakuan agen hayati (Gothandapani et al., 2014). Mekanisme antagonisme diamati pada pertumbuhan miselium agen hayati dan pathogen pada cawan petri dan di bawah mikroskop sesuai kriteria Trigiano et al. (2008) sebagai berikut: (a). Kompetisi, apabila pertumbuhan jamur antagonis lebih cepat untuk memenuhi cawan petri berdiameter $9 \mathrm{~cm}$ dan miselium jamur antagonis menutupi miselium patogen. Pada daerah kontak, hifa patogen mengalami lisis; (b). Antibiosis, apabila di antara jamur patogen dengan jamur antagonis terbentuk zona kosong, terdapat perubahan bentuk hifa patogen, dan dihasilkan pigmen di permukaan bawah koloni jamur antagonis; (c). Parasitisme, apabila hifa jamur antagonis tumbuh di atas hifa patogen, pada daerah kontak ditemukan hifa jamur antagonis.

\section{Uji Efikasi In Vivo}

Uji efikasi in vivo dilakukan dengan perlakuan benih dan menumbuhkan benih tersebut pada tanah yang diinfestasi $F$. oxysporum, sedang untuk kontrol benih direndam akuades steril. Perlakuan benih tomat dilakukan dengan cara merendam benih dalam suspensi agen hayati selama 25 menit sesuai dengan perlakuan, yaitu: 1). suspensi Trichoderma harzianum konsentrasi $10^{7} \mathrm{spora} / \mathrm{mL}$, 2).suspensi Gliocladium virens konsentrasi $10^{7}$ spora $/ \mathrm{mL}, 3$ ). kombinasi agensia hayati Trichoderma harzianum dan Gliocladium virens konsentrasi $10^{7} \mathrm{spora} / \mathrm{mL}$. Untuk masing-masing perlakuan direndam 100 benih tomat. Benih tomat yang sudah diperlakukan disemai pada potray yang diisi media tanah dan pupuk kandang yang sudah disterilkan kemudian diletakan di dalam screenhouse. Pada persemaian diamati Daya berkecambah, Indeks vigor, Potensi tumbuh benih dan Koefisien perkecambahan. Selanjutnya untuk mengetahui efektifitas agen hayati dalam mencegah layu Fusarium, bibit yang yang sudah diperlakukan tersebut ditanam pada polybag yang diinokulasi jamur F.oxysporum. Inokulasi dilakukan 7 hari sebelum tanam, dengan cara menyiramkan suspensi F.oxysporum sebanyak $10 \mathrm{~mL}$ di atas permukaan tanah dalam polybag $(20 \mathrm{~cm} \times 20 \mathrm{~cm})$. Bibit tomat berumur 21 hari dipindah tanam dari potray ke dalam polybag yang sudah diinokulasi F.oxysporum, setiap polybag ditanami satu bibit. Bibit Kontrol tanpa perlakuan (T0) ditanam pada tanah steril, bibit Kontrol dengan perlakuan (T1) ditanam pada tanah yang diinokulasi F.oxysporum. Sebagian bibit yang diberi perlakuan T.harzianum (T2) atau G.virens (T3) ditanam pada tanah steril untuk pembanding. 


\section{HASIL DAN PEMBAHASAN}

Pada umur 1 hsi (hari setelah inokulasi) sampai 2 hsi belum terlihat penghambatan pertumbuhan jamur patogen Fusarium oleh T.harzianum dan atau G. virens. Pertumbuhan patogen Fusarium pada masing-masing perlakuan mulai mengalami penghambatan pada umur 3 hsi sampai 7 hsi. Diameter pertumbuhan jamur F.oxysporum yang diberi perlakuan T.harzianum atau G.virens nyata lebih kecil daripada Fusarium tanpa agensia hayati (Tabel 1). Menurut Gothapani et al. (2014) penghambatan koloni patogen dari uji biakan ganda terjadi saat pertumbuhan jamur antagonis dan jamur patogen mengalami kontak. Pada umur 3 hsi sampai 7 hsi diketahui diameter Fusarium (kontrol) nyata lebih besar daripada perlakuan lainnya. Diameter F. oxysporum yang diberi perlakuan $T$. harzianum menunjukkan pertumbuhan patogen yang rendah daripada $F$. oxysporum tanpa jamur antagonis (kontrol) tetapi tidak berbeda nyata dengan pertumbuhan $F$. oxysporum yang diberi perlakuan $G$. virens atau kombinasi T.harzianum + G.virens (Tabel 1). Semakin kecil pertumbuhan koloni patogen maka semakin tinggi daya hambat jamur antagonis yang diberikan. Hal ini menunjukkan bahwa jamur $T$. harzianum dan $G$. virens merupakan jamur antagonis yang pertumbuhannya lebih cepat dibandingkan dengan jamur patogen karena adanya aktivitas persaingan tumbuh, ruang dan nutrisi dari jamur T. harzianum dan G. virens terhadap pathogen F. oxysporum. Yulianto (2014) menyebutkan, tingkat pertumbuhan antagonis yang tinggi menentukan aktivitas dalam menekan patogen target dengan kompetisi ruang dan nutrisi.

Tabel 1. Rerata diameter pertumbuhan jamur Fusarium (cm)

\begin{tabular}{llllllll}
\hline \multicolumn{1}{c}{ Perlakuan } & $\mathbf{1 ~ h s i}$ & $\mathbf{2} \mathbf{~ h s i}$ & $\mathbf{3 ~ h s i}$ & $\mathbf{4 ~ h s i}$ & $\mathbf{5 ~ h s i}$ & $\mathbf{6} \mathbf{h s i}$ & $\mathbf{7 ~ h s i}$ \\
\hline F. oxysporum (kontrol) & $0,8 \mathrm{a}$ & $2,5 \mathrm{a}$ & $4,1 \mathrm{a}$ & $5,8 \mathrm{a}$ & $7,0 \mathrm{a}$ & $7,5 \mathrm{a}$ & $9,0 \mathrm{a}$ \\
$\begin{array}{l}\text { F. oxysporum vs. T. } \\
\text { harzianum }\end{array}$ & $0,7 \mathrm{a}$ & $1,9 \mathrm{a}$ & $2,5 \mathrm{~b}$ & $2,7 \mathrm{~b}$ & $2,9 \mathrm{~b}$ & $3,1 \mathrm{~b}$ & $3,1 \mathrm{~b}$ \\
$\begin{array}{l}\text { F. oxysporum vs. G. } \\
\text { virens }\end{array}$ & $0,7 \mathrm{a}$ & $2,1 \mathrm{a}$ & $2,7 \mathrm{~b}$ & $2,8 \mathrm{~b}$ & $3,0 \mathrm{~b}$ & $3,1 \mathrm{~b}$ & $3,1 \mathrm{~b}$ \\
$\begin{array}{l}\text { F. oxysporum vs. T. } \\
\text { harzianum + G.virens }\end{array}$ & $0,5 \mathrm{a}$ & $1,5 \mathrm{a}$ & $2,0 \mathrm{~b}$ & $2,2 \mathrm{~b}$ & $2,4 \mathrm{~b}$ & $2,5 \mathrm{~b}$ & $2,5 \mathrm{~b}$ \\
\end{tabular}

Keterangan : Angka yang diikuti huruf yang sama dalam satu kolom menunjukkan tidak ada beda nyata berdasarkan uji jarak berganda Duncan pada taraf $5 \%$. hsi: hari setelah inokulasi.

Pemberian T.harzianum dan G.virens memberikan pengaruh nyata pada penekanan pertumbuhan Fusarium. Persentase daya hambat $T$. harzianum, $G$. virens, dan kombinasi T.harzianum + G.virens terhadap F. oxysporum tidak berbeda nyata (Tabel 2). Salah satu faktor yang mempengaruhi yaitu adanya kesamaan fungsi antagonis dari $T$. harzianum dan $G$. virens sehingga tidak menunjukkan adanya perbedaan yang nyata dari perlakuan tersebut. Penelitian Jangir et al. (2019) menunjukkan bahwa $T$. harzianum mempunyai sifat antagonisme yang sangat kuat terhadap $F$. oxysporum dengan persentase daya hambat mencapai $73,3 \%$. 
Tabel 2. Rerata persentase daya hambat jamur Trichoderma harzianum, Gliocladium virens, dan kombinasi T.harzianum + G. virens terhadap Fusarium oxysporum

\begin{tabular}{|c|c|c|c|c|c|c|c|}
\hline Perlakuan & 1 hsi & 2 hsi & 3 hsi & 4 hsi & 5 his & 6 hsi & 7 hsi \\
\hline $\begin{array}{l}\text { F. oxysporum } \\
\text { vs. T. harzianum }\end{array}$ & $18 \mathrm{a}$ & $21,3 \mathrm{a}$ & $37,3 \mathrm{a}$ & $51,8 \mathrm{a}$ & $57,3 \mathrm{a}$ & $56,8 \mathrm{a}$ & $64,8 \mathrm{a}$ \\
\hline $\begin{array}{l}\text { F. oxysporum } \\
\text { vs. G. virens }\end{array}$ & $15 a$ & $17,8 \mathrm{a}$ & $35,0 \mathrm{a}$ & $36,8 \mathrm{a}$ & $57,8 \mathrm{a}$ & $58,0 \mathrm{a}$ & $65,5 \mathrm{a}$ \\
\hline $\begin{array}{l}\text { F. oxysporum } \\
\text { vs. T.harzianum } \\
+ \text { G.virens }\end{array}$ & $38 \mathrm{a}$ & $34,5 \mathrm{a}$ & $47,5 \mathrm{a}$ & $59,0 \mathrm{a}$ & $64,3 \mathrm{a}$ & $64,0 \mathrm{a}$ & $71,8 \mathrm{a}$ \\
\hline
\end{tabular}

Tabel 3. Mekanisme Antagonisme T. harzianum dan G. virens terhadap F. oxysporum

\begin{tabular}{lccc}
\multicolumn{1}{c}{ Perlakuan } & Kompetisi & Antibiosis & Parasistisme \\
\hline $\begin{array}{l}\text { Penghambatan Pertumbuhan F. } \\
\text { oxysporum oleh T. harzianum }\end{array}$ & + & - & + \\
$\begin{array}{l}\text { Penghambatan Pertumbuhan F. } \\
\text { oxysporum oleh G. virens }\end{array}$ & + & - & + \\
$\begin{array}{l}\text { Penghambatan Pertumbuhan F. } \\
\text { oxysporum oleh Kombinasi }\end{array}$ & & & + \\
T.harzianum + G. virens & + & - & + \\
Keterangan: + : terjadi mekanisme antagonis; - : tidak terjadi mekanisme antagonis
\end{tabular}

Mekanisme antagonisme jamur $T$. harzianum dan $G$. virens terhadap $F$. oxysporum bersifat kompetisi dan parasitisme (Tabel 3). Mekanisme kompetisi dapat dilihat dari pertumbuhan masing-masing jamur yang saling bersentuhan dan tidak terbentuk zona hambatan maupun pertumbuhan salah satu koloni jamur yang menumpangi koloni jamur lainnya. Mekanisme parasitisme, apabila hifa jamur antagonis tumbuh diatas hifa patogen, pada daerah kontak ditemukan hifa jamur antagonis melilit hifa patogen, serta mengalami lisis sesuai kriteria Trigiano et al. (2008). Menurut Raka (2006) mekanisme kompetisi terjadi karena terdapat dua mikroorganisme yang secara langsung memerlukan nutrisi yang sama. Menurut Agustina (2013) Trichoderma sp. dapat menekan partumbuhan patogen dengan cara melilit hifa patogen, mengeluarkan enzim $\beta-1,3$ glukonase dan kitinase yang dapat menembus dinding sel inang. Selanjutnya Sudhanta (2010) menyatakan bahwa jamur endofit dan saprofit apabila ditumbuhkan bersama pada medium PDA dalam satu cawan petri tidak saling menghambat pertumbuhan, artinya kedua jamur ini di dalam tanah dapat bersinergis dalam mengendalikan jamur F. oxysporum. Penelitian Mukherjee et al. (1995) 
menunjukkan bahwa G. virens bersifat parasitik terhadap hifa dan sklerosia jamur Rhizoctonia solani.

Tabel 4. Daya berkecambah, Indeks vigor, Potensi tumbuh benih dan Koefisien perkecambahan benih yang diberi perlakuan agen hayati dan tanpa perlakuan

\begin{tabular}{lcccc}
\hline \multicolumn{1}{c}{ Perlakuan } & $\begin{array}{c}\text { Daya } \\
\text { Berkeca- } \\
\text { mbah (\%) }\end{array}$ & $\begin{array}{c}\text { Indeks } \\
\text { Vigor }\end{array}$ & $\begin{array}{c}\text { Potensi } \\
\text { Tumbuh } \\
\text { Benih }\end{array}$ & $\begin{array}{c}\text { Koefisien } \\
\text { Perkecam } \\
\text { bahan }\end{array}$ \\
\hline Kontrol Tanpa Perlakuan (T0) & $88 \mathrm{a}$ & $4,1 \mathrm{~d}$ & $97 \mathrm{a}$ & $97 \mathrm{a}$ \\
Trichoderma harzianum (T4) & $88 \mathrm{a}$ & $5,3 \mathrm{~b}$ & $97 \mathrm{a}$ & $97 \mathrm{a}$ \\
Gliocladium virens (T5) & $90 \mathrm{a}$ & $4,8 \mathrm{c}$ & $98 \mathrm{a}$ & $98 \mathrm{a}$ \\
T.harzianum +G.virens (T6) & $91 \mathrm{a}$ & $5,9 \mathrm{a}$ & $100 \mathrm{a}$ & $100 \mathrm{a}$ \\
\hline
\end{tabular}

Keterangan : Angka yang diikuti huruf yang sama dalam satu kolom menunjukkan tidak ada beda nyata berdasarkan uji jarak berganda Duncan pada taraf $5 \%$. hss : hari setelah semai

Perlakuan benih dengan T. harzianum atau G. virens atau T. harzianum + G. virens tidak berpengaruh nyata terhadap daya kecambah, potensi tumbuh benih dan koefisien perkecambahan, namun berpengaruh nyata terhadap indek vigor (Tabel 4). Indeks vigor pada perlakuan kombinasi Fusarium + T.harzianum +G.virens (T6) nyata lebih tinggi dibandingkan dengan perlakuan lainnya dan benih kontrol (T0) paling rendah indeks vigornya (Tabel 4). Hal ini dikarenakan benih tomat yang diberi perlakuan perendaman suspensi $T$. harzianum dan $G$. virens dapat menyerap nutrisi lebih baik dari pada benih tanpa perlakuan. Hasil ini sesuai dengan penelitian Zheng \& Shetty (2000) bahwa Trichoderma spp. menginduksi produksi senyawa fenolik selama perkecambahan biji dan senyawa fenolik yang dihasilkan oleh Trichoderma spp. menyebabkan peningkatan indeks vigor benih.

Tabel 5. Parameter tinggi tanaman (cm)

\begin{tabular}{lccc}
\hline \multicolumn{1}{c}{ Perlakuan } & $\mathbf{1 4}$ hst & 21 hst & 28 hst \\
\hline Kontrol Tanpa Perlakuan (T0) & $18,75 \mathrm{~b}$ & $29,67 \mathrm{~d}$ & $40,16 \mathrm{~d}$ \\
F. oxysporum (T1) & $18,83 \mathrm{~b}$ & $30,83 \mathrm{~cd}$ & $41,89 \mathrm{~cd}$ \\
Trichoderma harzianum (T2) & $18,58 \mathrm{~b}$ & $34,17 \mathrm{bcd}$ & $48,33 \mathrm{~b}$ \\
Gliocladium virens (T3) & $18,83 \mathrm{~b}$ & $37,50 \mathrm{ab}$ & $47,33 \mathrm{~b}$ \\
F. oxysporum vs. T. harzianum (T4) & $17,83 \mathrm{~b}$ & $29,67 \mathrm{~d}$ & $43,91 \mathrm{bcd}$ \\
F. oxysporum vs. G. virens (T5) & $19,50 \mathrm{~b}$ & $36,33 \mathrm{bc}$ & $45,83 \mathrm{bc}$ \\
F. oxysporum vs. T.harzianum +G.virens & $25,41 \mathrm{a}$ & $42,83 \mathrm{a}$ & $58,16 \mathrm{a}$ \\
(T6) & & &
\end{tabular}

Keterangan : Angka yang diikuti huruf yang sama dalam satu kolom menunjukkan tidak ada beda nyata berdasarkan uji jarak berganda Duncan pada taraf $5 \%$. hst : hari setelah tanam. 
Tinggi tanaman tomat umur 14 hst, 21 hst dan 28 hst pada perlakuan kombinasi Fusarium $+T$. harzianum + G.virens (T6) nyata lebih tinggi daripada perlakuan lainnya (Tabel 5). Hal ini menunjukkan pemberian jamur T.harzianum dan G.virens dapat meningkatkan pertumbuhan tanaman karena keberadaan agen antagonis selain mampu menekan perkembangan penyakit juga dapat menyediakan zat pengatur tumbuh. Hal ini didukung oleh Chet et al. (1979) bahwa cendawan T.harzianum telah digunakan dalam percobaan pengendalian hayati yang menunjukkan dapat meningkatnya kemampuan pertumbuhan tanaman. Beberapa spesies Trichoderma dan Gliocladium terbukti juga dapat menghasilkan zpt seperti Indol Acetid Acid (IAA), spesies Trichoderma akan mengkoloni dan tumbuh berasosiasi dengan perakaran tanaman (Harman et al., 2004a).

Tabel 6. Parameter jumlah daun (helai)

\begin{tabular}{lllll}
\hline \multicolumn{1}{c}{ Perlakuan } & $\mathbf{7}$ hst & $\mathbf{1 4}$ hst & $\mathbf{2 1}$ hst & $\mathbf{2 8}$ hst \\
\hline Kontrol Tanpa Perlakuan (T0) & $12,83 \mathrm{c}$ & $17,83 \mathrm{~b}$ & $27,50 \mathrm{~d}$ & $35,25 \mathrm{c}$ \\
F. oxysporum (T1) & $13,33 \mathrm{c}$ & $17,83 \mathrm{~b}$ & $27,83 \mathrm{~cd}$ & $35,00 \mathrm{c}$ \\
Trichoderma harzianum (T2) & $13,16 \mathrm{c}$ & $17,16 \mathrm{~b}$ & $32,58 \mathrm{bc}$ & $43,42 \mathrm{~b}$ \\
Gliocladium virens (T3) & $14,41 \mathrm{bc}$ & $18,00 \mathrm{~b}$ & $36,83 \mathrm{~b}$ & $46,83 \mathrm{~b}$ \\
F. oxysporum vs. T. harzianum (T4) & $12,91 \mathrm{c}$ & $16,83 \mathrm{~b}$ & $29,08 \mathrm{~cd}$ & $40,67 \mathrm{bc}$ \\
F. oxysporum vs. G. virens (T5) & $15,42 \mathrm{ab}$ & $18,58 \mathrm{~b}$ & $35,75 \mathrm{~b}$ & $43,33 \mathrm{~b}$ \\
F. oxysporum vs. T.harzianum +G.virens & $17,17 \mathrm{a}$ & $22,83 \mathrm{a}$ & $42,91 \mathrm{a}$ & $57,33 \mathrm{a}$ \\
(T6) & & & &
\end{tabular}

Keterangan : Angka yang diikuti huruf yang sama dalam satu kolom menunjukkan tidak ada beda nyata berdasarkan uji jarak berganda Duncan pada taraf $5 \%$. hst : hari setelah tanam.

Tanaman tomat yang diberi perlakuan kombinasi Fusarium vs. T.harzianum + G. virens (T6) memiliki rerata jumlah daun nyata lebih banyak dari pada jumlah daun pada perlakuan lainnya pada umur 7 hst, 14 hst, 21 hst dan 28 hst. Tidak terdapat beda nyata jumlah daun pada tanaman yang diberi perlakuan $T$. harzianum dengan $G$. virens yang dikombinasikan, karena keduanya menghasilkan senyawa fitohormon yang dapat memacu dalam proses perkembangan dan pertumbuhan tanaman. Trichoderma spp. mampu memacu pertumbuhan karena dapat mengendalikan patogen, meningkatkan serapan hara, meningkatkan metabolisme karbohidrat dan fotosintesis serta mampu mensintesa fitohormon indole acetic acid (IAA), dan mengatur keseimbangan hormone IAA, asam giberelin dan etilen (Stewart \& Hill, 2014). 
Tabel 7. Parameter bobot segar akar (gram)

\begin{tabular}{lccc}
\hline \multicolumn{1}{c}{ Perlakuan } & $\mathbf{1 4}$ hst & $\mathbf{2 1}$ hst & $\mathbf{2 8}$ hst \\
\hline Kontrol Tanpa Perlakuan (T0) & $0,15 \mathrm{~d}$ & $0,66 \mathrm{ab}$ & $0,93 \mathrm{bc}$ \\
F. oxysporum (T1) & $0,25 \mathrm{~cd}$ & $0,58 \mathrm{~b}$ & $0,68 \mathrm{c}$ \\
Trichoderma harzianum (T2) & $0,48 \mathrm{bc}$ & $0,79 \mathrm{ab}$ & $1,08 \mathrm{~b}$ \\
Gliocladium virens (T3) & $0.58 \mathrm{ab}$ & $0,75 \mathrm{ab}$ & $0,90 \mathrm{bc}$ \\
F. oxysporum vs. T. harzianum (T4) & $0,36 \mathrm{bc}$ & $0,63 \mathrm{~b}$ & $0,91 \mathrm{bc}$ \\
F. oxysporum vs. G. virens (T5) & $0,47 \mathrm{bc}$ & $0,77 \mathrm{ab}$ & $1,07 \mathrm{bc}$ \\
F. oxysporum vs. T.harzianum +G.virens (T6) & $0,66 \mathrm{a}$ & $1,01 \mathrm{a}$ & $1,62 \mathrm{a}$ \\
\hline
\end{tabular}

Keterangan : Angka yang diikuti huruf yang sama dalam satu kolom menunjukkan tidak ada beda nyata berdasarkan uji jarak berganda Duncan pada taraf $5 \%$. hst : hari setelah tanam.

Penimbangan bobot segar akar pada hari ke 7, 14, 21 dan 28 hst dilakukan untuk melihat hari kristis pada bobot akar terbaik. Pada perlakuan kombinasi $F$. oxysporum vs. T.harzianum + G.virens bobot segar akar nyata lebih tinggi daripada perlakuan lainnya (Tabel 7). Hal ini karena pada jamur Trichoderma diketahui dapat tumbuh berasosiasi dengan perakaran. Sedangkan Gliocladium dapat menyediakan ketersediaan hara untuk tanaman sehingga dapat meningkatkan bobot segar akar. Menurut Harman et al (2004a) pada jamur Trichoderma akan mengkoloni dan tumbuh berasosiasi dengan perakaran tanaman, sehingga tanaman dapat menyera unsur hara dengan lebih baik.

Tabel 8. Parameter bobot kering akar (gram)

\begin{tabular}{llll}
\hline \multicolumn{1}{c}{ Perlakuan } & 14 hst & 21 hst & 28 hst \\
\hline Kontrol Tanpa Perlakuan (T0) & $0,15 \mathrm{~b}$ & $0,27 \mathrm{~b}$ & $0,31 \mathrm{~b}$ \\
F. oxysporum (T1) & $0,14 \mathrm{~b}$ & $0,21 \mathrm{~b}$ & $0,26 \mathrm{~b}$ \\
Trichoderma harzianum (T2) & $0,14 \mathrm{~b}$ & $0,27 \mathrm{~b}$ & $0,41 \mathrm{~b}$ \\
Gliocladium virens (T3) & $0,19 \mathrm{ab}$ & $0,26 \mathrm{~b}$ & $0,45 \mathrm{~b}$ \\
F. oxysporum vs. T. harzianum (T4) & $0,16 \mathrm{ab}$ & $0,27 \mathrm{~b}$ & $0,32 \mathrm{~b}$ \\
F. oxysporum vs. G. virens (T5) & $0,23 \mathrm{ab}$ & $0,39 \mathrm{ab}$ & $0,47 \mathrm{~b}$ \\
F. oxysporum vs. T.harzianum +G.virens (T6) & $0,24 \mathrm{a}$ & $0,45 \mathrm{a}$ & $0,82 \mathrm{a}$ \\
\hline
\end{tabular}

Keterangan : Angka yang diikuti huruf yang sama dalam satu kolom menunjukkan tidak ada beda nyata berdasarkan uji jarak berganda Duncan pada taraf $5 \%$. hst: hari setelah tanam.

Bobot kering akar selaras dengan bobot segar akar pada umur 14 hst, 21 hst, dan 28hst perlakuan kombinasi Fusarium +T.harzianum +G. virens (T6) nyata lebih besar daripada perlakuan lainnya (Tabel 8). Hal tersebut menunjukkan bahwa pemberian agensia hayati mampu memacu pertumbuhan tanaman dengan baik sehingga terbentuk rambut-rambut akar yang baik. Jamur Trichoderma sp. dan Gliocladium diketahui dapat memacu pertumbuhan tanaman dan terbentuknya rambut-rambut akar yang banyak juga meningkatkan 
kemampuan menyerap hara dari dalam tanah sehinggg meningkatkan dalam bobot kering akar tanaman (Djatmiko \& Slamet, 1997).

Tabel 9. Parameter volume akar $(\mathrm{mL})$

\begin{tabular}{lccc}
\hline \multicolumn{1}{c}{ Perlakuan } & $\mathbf{1 4}$ hst & $\mathbf{2 1}$ hst & $\mathbf{2 8}$ hst \\
\hline Kontrol Tanpa Perlakuan (T0) & $0,15 \mathrm{e}$ & $0,40 \mathrm{~b}$ & $1,50 \mathrm{c}$ \\
F. oxysporum (T1) & $0,25 \mathrm{de}$ & $0,54 \mathrm{~b}$ & $1,50 \mathrm{c}$ \\
Trichoderma harzianum (T2) & $0,48 \mathrm{bc}$ & $0,66 \mathrm{ab}$ & $1,50 \mathrm{c}$ \\
Gliocladium virens (T3) & $0,58 \mathrm{ab}$ & $0,62 \mathrm{ab}$ & $1,50 \mathrm{c}$ \\
F. oxysporum vs. T. harzianum (T4) & $0,36 \mathrm{~cd}$ & $0,67 \mathrm{ab}$ & $1,50 \mathrm{c}$ \\
F. oxysporum vs. G. virens (T5) & $0,47 \mathrm{bc}$ & $0,79 \mathrm{ab}$ & $2,00 \mathrm{~b}$ \\
F. oxysporum vs. T.harzianum +G.virens (T6) & $0,66 \mathrm{a}$ & $1,01 \mathrm{a}$ & $2,10 \mathrm{a}$ \\
\hline
\end{tabular}

Keterangan : Angka yang diikuti huruf yang sama dalam satu kolom menunjukkan tidak ada beda nyata berdasarkan uji jarak berganda Duncan pada taraf $5 \%$. hst : hari setelah tanam.

Pada perlakuan kombinasi dari Fusarium vs. T.harzianum + G.virens (T6) umur 14 hst, 21 hst, 28 hst mempunyai pengaruh baik dalam perkembangan akar yang mampu menyerap dengan baik hara-hara yang ada pada Trichoderma dan Gliocladium (Tabel 9). Hal ini selaras dengan bobot segar akar dan bobot kering akar pada pertumbuhan tanaman tomat. Penyerapan air melalui akar dipengaruhi oleh turgiditas sel, diselubungi oleh hifa pada daerah rhizosfer sehingga berfungsi sebagai rambur-rambut akar, dan meningkatkan volume akar (Djatmiko \& Slamet 1997).

Tabel 10. Parameter persentase tanaman yang diserang F. oxysporum (\%)

\begin{tabular}{lcccc}
\hline \multicolumn{1}{c}{ Perlakuan } & $\mathbf{7 ~ h s t}$ & $\mathbf{1 4}$ hst & $\mathbf{2 1} \mathbf{~ h s t}$ & $\mathbf{2 8}$ hst \\
\hline Kontrol Tanpa Perlakuan (T0) & $0,0 \mathrm{c}$ & $0,0 \mathrm{c}$ & $0,0 \mathrm{c}$ & $0,0 \mathrm{~d}$ \\
F. oxysporum (T1) & $20 \mathrm{a}$ & $27,5 \mathrm{a}$ & $37,5 \mathrm{a}$ & $72,5 \mathrm{a}$ \\
Trichoderma harzianum (T2) & $0,0 \mathrm{c}$ & $0,0 \mathrm{c}$ & $0,0 \mathrm{c}$ & $0,0 \mathrm{~d}$ \\
Gliocladium virens (T3) & $0,0 \mathrm{c}$ & $0,0 \mathrm{c}$ & $0,0 \mathrm{C}$ & $0,0 \mathrm{~d}$ \\
F. oxysporum vs. T. harzianum (T4) & $7,5 \mathrm{~b}$ & $15,0 \mathrm{~b}$ & $17,5 \mathrm{~b}$ & $20,0 \mathrm{~b}$ \\
F. oxysporum vs. G. virens (T5) & $5,0 \mathrm{~b}$ & $12,5 \mathrm{bc}$ & $17,5 \mathrm{~b}$ & $20,0 \mathrm{~b}$ \\
F. oxysporum vs. T.harzianum +G.virens (T6) & $0,0 \mathrm{bc}$ & $5,0 \mathrm{bc}$ & $5,0 \mathrm{~b}$ & $10,0 \mathrm{c}$ \\
\hline
\end{tabular}

Keterangan : Angka yang diikuti huruf yang sama dalam satu kolom menunjukkan tidak ada beda nyata berdasarkan uji jarak berganda Duncan pada taraf $5 \%$. hst : hari setelah tanam.

Pada tanaman Kontrol tanpa perlakuan (T1) dan tanaman yang diberi perlakuan T.harzianum (T2) atau G.virens (T3) yang ditanam pada tanah tanpa inokulasi $F$. oxysporum tidak ada yang terserang $F$. oxysporum, hal ini menunjukkan bahwa benih yang dipakai tidak tertular atau terinfeksi $F$. oxysporum. Persentase tanaman terserang umur 7 hst, 14 hst, 21 hst dan 28 hst pada perlakuan $F$. oxysporum (T1) nyata lebih besar daripada semua perlakuan (Tabel 10). Hal ini terjadi karena pada perlakuan F. oxysporum (T1) tidak 
diberikan agen antagonis sehingga tidak dapat melindungi tanaman dari serangan F. oxysporum. Gejala layu Fusarium secara visual pada tanaman yang terinfeksi adalah tepi bawah daun menjadi kuning tua, merambat ke bagian dalam secara cepat sehingga seluruh permukaan daun tersebut menguning (Srinivas et al., 2019). Gejala tersebut muncul karena patogen F. oxysporum yang terus berpenetrasi ke dalam jaringan tanaman. Tanaman yang diberi perlakuan kombinasi agen hayati $T$. harzianum dan $G$. virens terlihat dapat menekan serangan $F$. oxysporum lebih baik dari pada apabila kedua agen hayati tersebut diaplikasikan secara terpisah (Tabel 10). Sudhanta (2010) menunjukkan bahwa Trichoderma dan Gliocladium mampu menginduksi ketahanan tanaman terhadap penyakit layu Fusarium.

Pengamatan keparahan penyakit pada perlakuan Fusarium (T1) secara tunggal terlihat nyata lebih tinggi daripada perlakuan lainya (Tabel 11). Hal ini dapat disebabkan tidak adanya hambatan dari agensia hayati bagi patogen untuk menginfeksi dan berinvasi di dalam jaringan tanaman. Infeksi $F$. oxysporum pada akar tanaman tomat yang rentan dapat berkembang ke xilem dan berlanjut ke batang yang mengakibatkan gangguan transportasi air, sehingga muncul gejala penguningan pada daun (Srinivas et al., 2019). Pada tanaman yang diberi perlakuan kombinasi jamur antagonis $T$. harzianum dan $G$. virens nyata mampu menekan keparahan penyakit akibat serangan patogen $F$. oxysporum lebih baik dari pada jika kedua jamur antagonis tersebut diaplikasikan sendiri-sendiri. Menurut Purwantisari \& Hastuti (2009) Trichoderma sp. dan Gliocladium sp. selain memiliki mekanisme pengendalian yang spesifik target, jamur juga dapat mengkoloni rizosfer dengan cepat dan melindungi akar dari serangan jamur patogen.

Tabel 11. Parameter keparahan penyakit (\%)

\begin{tabular}{lc}
\hline \multicolumn{1}{c}{ Perlakuan } & $\begin{array}{c}\text { Rerata Keparahan } \\
\text { Penyakit (\%) }\end{array}$ \\
\hline Kontrol Tanpa Perlakuan (T0) & $0,0 \mathrm{c}$ \\
F. oxysporum (T1) & $54,2 \mathrm{a}$ \\
Trichoderma harzianum (T2) & $0,0 \mathrm{c}$ \\
Gliocladium virens (T3) & $0,0 \mathrm{c}$ \\
F. oxysporum vs. T. harzianum (T4) & $7,5 \mathrm{~b}$ \\
F. oxysporum vs. G. virens (T5) & $5,9 \mathrm{~b}$ \\
F. oxysporum vs. T.harzianum +G.virens (T6) & $1,7 \mathrm{c}$ \\
\hline
\end{tabular}

Keterangan : Angka yang diikuti huruf yang sama dalam satu kolom menunjukkan tidak ada beda nyata berdasarkan uji jarak berganda Duncan pada taraf $5 \%$.

\section{KESIMPULAN}

Jamur T.harzianum dan G.virens mempunyai sifat antagonis terhadap jamur patogen $F$. oxysporum dengan mekanisme kompetisi dan parasitisme. Perlakuan benih tomat dengan kombinasi T.harzianum dan G.virens dapat menekan serangan F. oxysporum lebih baik dari pad ajika diaplikasikan terpisah. 


\section{UCAPAN TERIMAKASIH}

Terima kasih kepada LPHPT (Laboratorium Pengamatan Hama dan Penyakit Tumbuhan), Bantul yang telah menyediakan tempat dan fasilitas penelitian ini.

\section{DAFTAR PUSTAKA}

Agrios, G. N., 1996. Ilmu Penyakit Tumbuhan. Edisi Ketiga.UGM-Press, Yogyakarta.

Agustina, I, 2013. Uji Efektifitas Jamur Antagonis Trichodherma sp. dan Gliocladium sp. Untuk Mengendalikan Penyakit Lanas (Phytopthora nicotianae) Pada Tanaman Tembakau Deli (Nicotiana tabaccum L.). [Skripsi]. USU. Medan

Bertoldo, C., Gilardi, G., Spadaro, D., Gullino, M.L. \& Garibaldi, A. 2015. Genetic diversity and virulence of Italian strains of Fusarium oxysporum isolated from Eustomagrandiflorum. European Journal of Plant Pathology 141: 83-97.

Cha, J.Y., Han,S., Hong,H.J., Cho, H., Kim, D., Kwon, Y., Kwon, S.K., Crüsema nn, M., Lee, Y.B., Kim, J.F., Giaever, G., Nislow, C., Moore,B.S., Thomash ow, L.S., Weller, D.M. \& Kwak Y.S. 2016. Microbial and biochemical basis of a Fusarium wilt suppressive soil. ISME Journal 10: 119-129

Chet, I., Y. Hadar, J. Katan and Y. Henis. 1979. Biological Control of Soil-Brone Plant Pathogens by Trichoderma harzianum. In SoilBorne Plant Pathogens. Eds. B. Schippers and W. Gams. pp. 585- 592. Academic Press, London

Djatmiko \& Slamet 1997. Efektivitas Trichoderma harzianum dalam sekam padi dan bekatul terhadap pato-genitas Plasmodium brassicae pada tanah latosol dan andosol. Majalah Imiah UNSOED. 2: 10-22

Ferrigo, D., Raiola, A., \& Scopel, C., 2014. T.harzianum T22 induces in maize systemic resistance against Fusarium verticillioides. Journal of Plant Pathology 96(1):133-142.

Fravel, D., Olivain, C., \& Alabouvette, C. 2003. Fusarium oxysporum and its biocontrol. New phytologist: 157: 493-502.

Gava, C.A.T \& Pinto, J.M. 2016. Biocontrol of melon wilt caused by Fusarium oxysporum Schlect f. sp. melonis using seed treatment with Trichoderma spp. and liquid compost. Biological Control. 97: 13-20.

Gothandapani, S., Boopalakrishnan, G., Prabhakaran, N., Chethana, B.S., Aravindhan, M., Saravanakumar, M. \& Ganeshan, G. 2014. Evaluation of entomopathogenic fungus against Alternaria porri (Ellis) causing purple blotch disease of onion. Journal. Phytopathology and Plant Protection 48: 135-144.

Ghufron, M., Nurcahyanti, S.D., \& Wahyuni, W.S. 2017. Pengendalian Penyakit Layu Fusarium dengan Trichoderma sp. pada Dua Varietas Tomat J. Agrotek. Trop. 6 (1): 29-34

Harman, G. E., Petzoldt R., Comis A., Chen J. 2004a. Interaction between Trichoderma harzianum Strain T22 and Maize Inbred Line Mo17 and Effects of These Interactions on Disease Caused by Phytium ultimum and Colletotrichum graminicola. Journal Phytopathology 94: 147-153. 
Harman, G.E., Howell, C.R., Viterbo, A., Chet, I., Lorito, M. 2004b. Trichoderma species, opportunistic, avirulent plantsymbionts. Nature Reviews Microbiology 2:43-56.

Howell, C.R. 1982. Effect of Gliocladium virens on Pythium ultimum, Rhizoctonia solani, and damping-off of cotton seedlings. Phytopathology 72: 496-498.

Jangir, M., Sharmaa, S. \& Sharma, S. 2019. Target and non-target effects of dual inoculation of biocontrol agents against Fusarium wilt in Solanum lycopersicum. Biological Control 138: 104069. https://doi.org/10.1016/j.biocontrol.2019.104069.

Khan, N., Maymon, M., Hirsch, A.M. 2017. Combating Fusarium infection using bacillus- based antimicrobials. Microorganisms 5: 75

McGovern, R.J. 2015. Management of tomato diseases caused by Fusarium oxysporum, Crop Protection 73: 78-92.

Mukherjee, P. K., Mukhopadhyay, A. N., Sarmah, D. K. \& Shrestha, S. M. 1995. Comparative Antagonistic Properties of Gliocladium virens and Trichoderma harzianum on Sclerotium rolfsii and Rhizoctonia solani-its Relevance to Understanding the Mechanisms of Biocontrol. Journal of Phytopathology 143: 275-279.

Purwantisari, S. \& Hastuti, R.B. 2009. Uji antagonisme jamur patogen Phytophthora infestans penyebab penyakit busuk daun dan umbi tanaman kentang dengan menggunakan Trichoderma spp. isolat lokal. Bioma Jurnal 11(1):24-32.

Raka, I.G. 2006. Eksplorasi dan Cara Aplikasi Agensia Hayati Trichoderma sp. Sebagai Pengendali Organisme Pengganggu Tumbuhan (OPT). Dinas Pertanian Tanaman Pangan UPTD Balai Proteksi Tanaman Pangan dan Holtikultura

Sudhanta, I. M, 2010. Pengujian Beberapa Jenis Jamur Endofit Dan Saprofit Trichoderma Spp. Terhadap Penyakit Layu Fusarium Pada Tanaman Kedelai. [Skripsi]. Universitas Mataram.

Supriati, Y. \& Siregar, F. D. 2009. Bertanam Tomat dalam Pot dan Polybag. Penebar Swadaya: Jakarta.

Srinivas, C., Devi, D.N., Murthy, K.N., Mohan, C.D., Lakshmeesha, T.R., Singh, B., Kalagatur, N.K., Niranjana, S.R., Hashem, A., Alqarawi, A.A., Tabassum, B., Abd_Allah, E.F., Nayaka, S.C. \& Rakesh K. Srivastava, R.K. 2019. Fusarium oxysporum $f$. sp. lycopersici causal agent of vascular wilt disease of tomato: Biology to diversity-A review, Saudi Journal of Biological Sciences 26: 1315-1324

Stewart, A. \& Hill, R. 2014. Applications of Trichoderma in Plant Growth Promotion, In: Editor(s): Vijai K. Gupta, Monika Schmoll, Alfredo HerreraEstrella, R.S. Upadhyay, Irina Druzhinina, Maria G. Tuohy, Biotechnology and Biology of Trichoderma, Elsevier, pp.415-428.

Stinson, M., Ezra, D., Hess, W.M., Sears, J. \& Strobel, G. 2003. An endophytic Gliocladium sp. of Eucryphia cordifolia producing selective volatile antimicrobial compounds. Plant Science 165: 913-922.

Trigiano, R. N., Windham, M. T. \& Windham, A. S. 2008. Plant pathology: Concepts and laboratory exercises. Second Edition. New York: CRC Press. p. 558 
Yulianto, E. 2014. Evaluasi Potensi Jamur Agen Antagonis dalam Menghambat Patogen Fusarium sp. pada Tanaman Jagung. [Skripsi]. Universitas Bengkulu.

Zheng, Z \& K. Shetty. 2000. Enhancement of Pea (Pisum Sativum) Seedling Vigour And Associated Phenolic Content By Extracts Of Apple Pomace Fermented With Trichoderma spp. Process Biochemistry 36: 79-84. 